\title{
TRANSFORMASI GERAKAN SOSIAL KE PARTAI POLITIK KIPRAH POLITIK PARTAI RAKYAT DEMOKRATIK DI MASA REFORMASI.
}

\author{
Gili Argenti \\ FISIP-Universitas Negeri Singaperbangsa, Karawang \\ E-mail: giliunsika@yahoo.co.id
}

\begin{abstract}
ABSTRAK
Pada masa Orde Baru berkuasa, yaitu diakhir tahun1970-an sampai awal tahun 1990-an, gerakan mahasiswa dihadapkan dengan tindakan represif, kebijakan membatasi aktifitas politik mahasiswa diberlakukan, maka pencarian akan format baru gerakan merupakan keharusan. Kelompok studi menjadi pilihan untuk menghindari tangan-tangan kekuasaan. Dalam perkembanganya, kelompok studi berubah menjadi partai politik, yaitu Partai Rakyat Demokratik (PRD). Kemunculan PRD sebagai partai oposisi terhadap Orde Baru mencuri perhatian publik politik Indonesia, karena program-program politik mereka sangat radikal, selain itu stigma komunis yang dilekatkan pemerintah terhadap partai anak muda ini menuai reaksi pro-kontra di masyarakat. Pasca runtuhnya Orde Baru PRD sempat menjadi partai elektoral, tetapi gagal menuai dukungan pemilih. Tulisan ini menjelaskan proses perubahan format gerakan mahasiswa era 1990-an, dari kelompok studi menjadi komite-komite aksi, kemudian menjadi partai politik, selain itu dalam tulisan ini juga dijelaskan kiprah politik PRD di era reformasi.
\end{abstract}

Kata kunci: Gerakan Sosial, Partai Rakyat Demokratik, PRD

\section{TRANSFORMATION OF SOCIAL MOVEMENT TO POLITICAL PARTY: THE PACE OF PEOPLE DEMOCRATIC PARTY (PRD) IN REFORMATION PERIOD}

\section{ABSTRACT}

In the New Order era (Orde Baru), the end of the 1970s until the early 1990s, the student movement is faced with repressive measures, a policy of limiting the political activities of students applied, then the search of a new format motion is a must. The study group be an option to avoid the political power. In the expansion, the study group turn into a political party, the People's Democratic Party (PRD). The emergence of the PRD as an opposition party to the New Order Indonesian political public attention, because of their political program is so radical, also communist stigma attached by the government against the party's young people reap the reaction of pro and cons in the community. After the collapse of the New Order, PRD became an electoral party, but failed to reap the support of voters. This paper describes the process of changing the format of the student movement of the 1990s, from the study group into action committees, later became a political party, in this paper also described the political progress of PRD in the reform era.

Keywords: social movements, people's democratic, PRD

\section{PENDAHULUAN}

Pasca gerakan mahasiswa tahun 1977/78 di kampus ITB, pemerintah Orde Baru di bawah Presiden Soeharto merespon kegelisahan anakanak muda ini dengan mengeluarkan kebijakan pembekukan Dewan Mahasiswa (DM) untuk kemudian digantikan oleh Normalisasi Kehidupan Kampus (NKK) dan Badan Koordinasi Kemahasiswaan (BKK), Dewan Mahasiswa merupakan sebuah organisasi intra kampus, yang sepanjang tahun 1970-an menjadi alat mobilisasi mahasiswa dalam melakukan aksi-aksi protes terhadap pemerintah.

Dampak dari pembekuan DM menjadikan mahasiswa kehilangan otonomi politiknya, mereka menjadi kehilangan ruang yang bebas dalam membangun aktifitas kreatif, karena hanya melalui DM ruang itu memungkinkan mahasiswa menggeluti politik, walaupun sebatas teori, konsep dan aktifitas ilmiah. Dampak lainnya dari pembekuan DM, mahasiswa men- 
Kehadiran SMPT menarik minat sebagian organisasi mahasiswa ekstra kampus untuk berkompetisi memperebutkan lembaga kemahasiswaan ini. Kelompok mahasiswa ekstra kampus berpikiran "moderat" mencoba menguasai senat dan unit kegiatan mahasiswa, dengan tujuan memperbesar pengaruh mereka di dalam kampus, orientasi mereka yang moderat, serta cenderung pro-birokrat kampus, membuat kelompok mahasiswa radikal menarik diri dari politik kampus dan menuduh mereka yang moderat membawa agenda rezim Orde Baru ke dalam kampus. Sebaliknya, organisasi mahasiswa ekstra kampus, terutama Himpunan Mahasiswa Islam (HMI) menuding mahasiswa radikal penentang SMPT adalah organ binaan orang-orang komunis (Gunawan, et al., 2009:78).

Sebagian kelompok-kelompok mahasiswa radikal yang embrio awalnya dari kelompok studi ini, tetap memilih jalan perjuangan dengan berintergrasi dengan rakyat, di Yogakarta para aktifis mahasiswa radikal ini kemudian mendirikan Solidaritas Mahasiswa Yogyakarta, umumnya anggotanya berasal dari kampus UII dan UGM, dengan konsentrasi tetap melakukan aktifitas mengorganisir kekuatan-kekuataan progresif ditengah-tengah masyarakat. Organisasiorganisasi semacam SMY kemudian berkembang disejumlah kota, organisasi-organisasi itulah kemudian melakukan kongres yang membentuk Persatuan Rakyat Demokratik (PRD).

Pada tanggal 2 Mei 1994 dideklarasikan Persatuan Rakyat Demokratik (PRD) yang diketuai Sugeng Bahagijo, kongres organisasiorganisasi mahasiswa selama tiga hari ini, selain membentuk PRD, juga membentuk organisasi-organisasi sektoral massa rakyat, seperti Solidaritas Mahasiswa Indonesia Untuk Demokrasi (SMID) untuk kalangan mahasiswa, kalangan buruh didirikan Pusat Perjuangan Buruh Indonesia (PPBI), kalangan petani dikonsolidasikan ke dalam Serikat Tani Nasional (STN), sedangkan untuk kalangan seniman berdiri Jaringan Kerja Kesenian Rakyat (JAKER) (Gunawan,1999:21)

Akan tetapi, PRD dibawah kepemimpinan Sugeng Bahagijo ternyata memiliki kecenderungan seperti politisi elit Indonesia, menyampaikan kritik terhadap pemerintah Orde Baru melalui retorika verbal melalui media, bukan dengan aksi massa rakyat yang tersadarkan, hal ini kemudian mengundang ketidakpuasaan anggota PRD lain. Maka diadakanlah Kongres Luar Biasa (KLB) PRD di bulan April 1996, kongres itu berlangsung secara rahasia, karena tidak mungkin sebuah kekuataan oposisi berkongres secara terbuka dibawah kekuasaan rezim Orde Baru, salah satu keputusan terpenting dalam kongres, yaitu merubah bentuk PRD dari organisasi "persatuan" menjadi "partai politik", Budiman Sudjatmiko terpilih sebagai Ketua Umum PRD. (Gunawan,1999:80-81)

Partai Rakyat Demokratik (PRD) dideklarasikan tanggal 22 Juli 1996 di Kantor YLBHI Jakarta, dalam deklarasi itu, PRD mengeluarkan manifesto perjuangan yang dikenal dengan "Manifesto PRD", isinya diantaranya:

1.Mencabut paket UU Politik dan semua peraturan yang bertentangan dengan pasal 28 UUD 1945.

2.Hak mendirikan partai politik selain yang ada sekarang, dan partai tersebut diberikan kebebasan untuk melaksanakan programprogramnya.

3.Jaminan bebas dari ancaman kekerasan militer dengan pengukuhan supremasi sipil (dihapuskannya dwifungsi ABRI), mengembalikan militer ke barak.

4.Mendesak MPR untuk mengadakan Sidang Istimewauntukmenuntutpertanggungjawaban Soeharto selama memimpin negara Republik Indonesia.

Manifesto politik PRD pada masanya terbilang berani serta radikal, menuntut perubahan sistemik Orde Baru untuk menjadi rezim yang lebih demokratis, tentu tuntutan anak-anak muda radikal ini dijawab pemerintahan Orde Baru, dengan cara-cara yang represif.

Pasca peristiwa 27 Juli 1996 partai berbasis anak-anak muda ini resmi dilarang pemerintah, pelarangan dikeluarkan setelah PRD dituduh sebagai dalang dibalik kerusuhan yang membakar Jakarta selama beberapa hari, selain melarang PRD, pemerintah Orde Baru juga memburu para pimpinannya dan anggotanya. Bahkan, sampai sekarang tokoh-tokoh kunci PRD belum diketahui keberadaannya, seperti Wiji Thukul, Herman Hendrawan, Suyat dan Bimo Petrus Anugrah.

Setelah keruntuhan Orde Baru, PRD kembali menjadi partai politik yang bergerak secara legal, serta sempat menjadi peserta Pemilu 
(Hasibuan, 2008)

Dalam studinya David F Aberle (dalam Damsar, 2010,133-135), menjelaskan ada empat tipe atau jenis gerakan sosial, yaitu: (1) Gerakan sosial alternatif (alterative social movement), gerakan yang bertujuan mengubah perilaku tertentu dalam diri individu. Dalam tipe ini mencakup berbagai kegiatan seperti kampanye anti narkoba, anti sek bebas dan sebagainya. (2) Gerakan sosial redemptif (redemptive social movement), gerakan yang bertujuan mengubah keseluruhan perilaku individu, gerakan ini memiliki sasaran yang sama dengan gerakan sosial alteratif, namun berbeda dalam cakupan. Gerakan sosial redemptif merubah perilaku lama menjadi perilaku baru yang berbeda sama sekali dengan yang lama. Contohnya gerakan yang diajukan biasanya gerakan keagamaan seperti gerakan fundamentalis keagamaan. (3) Gerakan sosial reformatif (reformative social movement), gerakan perubahan atau reformasi pada segi atau bagian tertentu dari masyarakat. Gerakan sosial ini jelas berbeda dengan dua gerakan yang disebut lebih awal yang menekankan pada individu. (4) Gerakan sosial tranformatif (transformative social movement), gerakan untuk mentrasformasikan tatanan sosial itu sendiri, para anggotanya memiliki kehendak mengubah tatanan sosial masyarakat menjadi tatanan yang lebih baik menurut versi mereka.

Menurut Bagus Takwin (2009: 5), dalam konteks gerakan sosial,ideologi seringkalidigunakan sebagai dasar bagi usaha pembebasan manusia, dalam hal ini ideologi memiliki pengertian sebagai sekumpulan gagasan yang menjadi panduan bagi sekelompok manusia dalam bertingkah laku mencapai tujuan tertentu. Dengan cara menurunkan gagasangagasan ideologi menjadi sejumlah kerangka aksi dan aturan-aturan tindakan, sekelompok manusia bertindak membebaskan diri dari sesuatu yang dipersepsikan sebagai kekangan atau penindasan. Ideologi memberi arah bagi gerakan pembebasan, serta menjadi keyakinan bagi kelompok tersebut.

\section{HASIL DAN PEMBAHASAN}

\section{Transformasi Gerakan Sosial Menjadi Partai Politik}

Akibat kebijakan NKK/BKK, mahasiswa kehilangan cirinya yang utama sebagai kekuatan kritis terhadap penguasa, apatisme pun melanda sikap mahasiswa, mereka tidak lagi memiliki kepedulian yang terefleksikan secara nyata melalui aksi-aksi protes terhadap masalah-masalah sosial politik yang berkembang di luar kampus, sikap apatis ini boleh jadi karena dibayangi kekhawatiran akan adanya sanksi akademis yang ketat, tetapi sebagian lainnya disebabkan ketiadaan wadah(Dewan Mahasiswa) yang dapat digunakan sebagai wahana artikulasi kritis mahasiswa (Culla,1999:126).

Kendati demikian, kecenderungan apatisme ini tidak sampai meluas melanda seluruh mahasiswa, juga tidak sampai berkembang menjadi sikap fantalis secara komunal, mengakibatkan mahasiswa yang memiliki ciri kritis kemudian tenggelam dalam frustasi politik yang berlarut-larut. Hal ini disebabkan dalam proses kevakuman tersebut, terdapat sebagian mahasiswa yang masih memiliki kepekaan sosial dan komitmen politik moral, akhirnya menemukan alternatif baru gerakan untuk dapat terus menjaga kelangsungan tradisi kritis yang sudah mengakar dalam dunia kampus (Culla, 1999:126).

Sebagai alternatif terhadap suasana kampus yang apolitik, dikembangkanlah medan berkiprah baru dikalangan mahasiswa, yang dianggap tidak akan tersentuh oleh kekuasaan represif penguasan Orde Baru. Medan baru itu yaitu kelompok studi (study club), melalui kelompok-kelompok studi ini mahasiswa bermaksud tetap merawat kesadaran kritis ditengah-tengah sistem politik yang tidak memberikan ruang kebebasan bagi mereka (Culla, 1999:126-127).

Kemunculan kelompok-kelompok studi ini menandakan fase baru dalam tubuh gerakan mahasiswa, setelah sebelumnya gerakan mahasiswa identik dengan aksi mobilisasi massa melakukan aksi demonstrasi, maka melalui kelompok studi kemampuan analisa mahasiswa semakin diasah melalui berbagai referensi teoriteori sosial yang ketika itu menjadi bacaan wajib dikelompok-kelompok studi.

Tekanan yang dilakukan penguasa Orde Baru terhadap mahasiswa melalui kebijakan $\mathrm{NKK} / \mathrm{BKK}$, justru mendorong lahirnya format baru gerakan di dalam tubuh mahasiswa, jika kampus sudah tidak lagi memberi ruang aman dan lapang bagi tumbuhnya idealisme, maka arena di luar kampus memberi tempat yang luas 
di Bawah Allende" menjadi salah satu referensi penting yang menjadi rujukan aktifis di kelompok studi ini (Sujdatmiko,2013:263-264).

Kegandrungan anak-anak muda ini terhadap wacana dan teori kiri, menurut Goenawan Muhammad (Jurnal Kalam, edisi 1 Tahun 1994), awalnya merupakan keingintahuan mereka terhadap "sesuatu" yang dilarang pemerintah untuk dipelajari, ternyata sesuatu itu membangkitkan kesadaran kritis mereka atas jalannya praktek kapitalisme di Indonesia, sehingga "sesuatu" itu memikat anak-anak muda ini yang secara diamdiam terus intens dipelajari dan didiskusikan. Sedangkan, menurut Daniel Dhakidae (2003), pilihan anak-anak muda terhadap wacana dan teori kiri lebih pada suatu gerakan kebudayaan untuk menentang apa saja yang dilarang oleh negara, semakin dilarang anak-anak muda ini semakin penasaran, ingin mengetahui kenapa sesuatu itu dilarang. Gerakan kebudayaan dengan kembali menghidupkan wacana dan teori kiri, tentunya selain sebagai wacana perlawanan, juga bertujuan untuk mengimbangi dominasi produksi wacana kanan kapitalisme pembangunan dari negara.

Selain kemunculan kelompok-kelompok studi secara massif, juga penting dicatat ialah maraknya penerbitan-penerbitan mahasiswa, meskipun penerbitan ini dikelola lembaga-lembaga resmi kemahasiswaan (press kampus), namun penerbitan ini banyak menarik sebagian besar kalangan mahasiswa kritis. Beberapa penerbitan penting serta banyak berperan dalam menumbuhkan budaya kritis mahasiswa diantaranya, Warta UI (Universitas Indonesia), Politika (Universitas Nasional), Ganesha (ITB, Bandung), Hayam Wuruk (Universitas Diponegoro, Semarang) dan Arena (IAIN Suka, Yogyakarta). (Sidiq, 2003:60)

Dalam perkembangnya kemudian, kelompok studi ini tidak bertahan lama, karena dinilai terlalu elitis hanya mendiskusikan teori-teori yang melangit, menjauhkan mahasiswa dari realitas riil masyarakat, mereka terjebak romantisme ide dan gagasan revolusioner, tetapi tidak mampu menjadikan ide dan gagasan itu menjadi energi perubahan, sehingga format gerakan kelompok studi dianggap gagal mendorong transformasi sistem politik Orde Baru ke arah lebih demokratis. Maka memasuki tahun 1990an terjadi perubahan pola gerakan mahasiswa yang signifikan, dari kelompok studi yang mendiskusikan wacana pemikiran di ruang-ruang tertutup yang bersifat teoritis, menjadi gerakan mahasiswa yang menempuh jalur praktis, melalui pembentukan Komite-Komite Aksi (KS) dan Organisasi Masyarakat (ormas).

Dalam mengorganisasikan aksi-aksi protesnya ini, mahasiswa menggunakan nama komite sebagai identitas, pencantuman nama komite bertujuan selain untuk mengidentifikasi persoalan yang mereka protes, juga menghindari tekanan pihak kampus yang tidak membolehkan mahasiswa yang aktif diluar kampus menggunakan nama almamater kampusnya. Adapun, beberapa permasalahan sosial yang disuarakan mahasiswa melalui komite aksi diantaranya kasus korupsi, hak asasi manusia, lingkungan hidup, hak-hak buruh dan soal pertanahan. Di samping itu, terdapat beberapa kasus lain yang lebih spesifik seperti kasus Waduk Kedung Ombo, Belangguan, Kacapiring, Cimacan, Badega dan Cilacap.

Kemunculan komite aksi dan organisasi massa sesungguhnya hasil dari kontemplasi yang dilakukan para aktifis kelompok studi, pemahaman mereka secara teoritik melalui studi literatur, telah mengantarkan mereka akan kesadaran bahwa telah terjadi ketimpangan kondisi sosial-politik di lapangan, sehingga kesadaran untuk mengaplikasikan teori-teori dalam tataran praktis menjadi kebutuhan yang mendesak mentransformasi sistem politik ke arah lebih baik.

Pada tanggal 2 Mei 1994, sekitar 40 aktifis dari komite aksi dan ormas lintas sektoral, berkumpul di kantor Yayasan Lembaga Bantuan Hukum Indonesia (YLBHI), Jakarta, untuk mendeklarasikan organisasi politik baru, yaitu Persatuan Rakyat Demokratik (PRD) yang mewadahi berbagai organisasi perlawanan mahasiswa, buruh dan petani. Dalam deklarasi pendiriannya, PRD menuntut adanya perbaikan hak-hak demokrasi, supremasi sipil dan distribusi kesejahteraan masyarakat (Max Lane, 2014:192). Ketika pendiriaanya yang ditunjuk sebagai ketua ialah Sugeng Bahagio, ketika itu Ketua Senat Mahasiswa Fakultas Filsafat Universitas Gadjah Mada (UGM), sementara Tumpak Sitorus menjadi Sekjennya, Andi Arief duduk sebagai Seksi Penelitian dan Pengembangan dan Ambar mengelola Seksi Dana (Fatah, 2000:99).

Persatuan Rakyat Demokratik (PRD) di bawah kepemimpinan Sugeng Bahagijo, 
jadi kehilangan basis organisasinya, sebelumnya DM menjadi organisasi yang efektif dalam melakukan mobilisasi massa mahasiswa dari seluruh fakultas yang ada di dalam kampus (Adi Suryadi Culla,1999)

Konsep NKK/BKK merupakan pemikiran yang dirumuskan oleh Mentri Pendidikan dan Kebudayaan saat itu, Daoed Joesoef, dengan tujuan mengatur kehidupan kampus supaya lebih kondusif, karena menurutnya aktifis mahasiswa melalui DM berperilaku lebih dari seorang politisi dari pada sebagai individu yang sedang belajar dibangku perguruan tinggi. Hal ini terjadi karena kurikulum di perguruan tinggi kurang mengarahkan mahasiswa menjadi manusia penganalisa.

"Mahasiswa selama ini melupakan misi pokoknya, mereka mengklaim dirinya mahasiswa tetapi bertindak sebagai politisi, kalau mereka benar politisi, mereka harus bersedia mendefinir dirinya sebagai politisi, kurikulum tidak mendorong ke arah menjadikan mereka manusiapenganalisa.Mahasiswaharusmenjadi manusia the man of analysis, bukan manusia rapat umum" (Budiyarso, 2000:273)

Menurut Adi Suryadi Culla (1999:125126), akibat dari kebijakan NKK/BKK ini menjadikan mahasiswa kehilangan ciri utamanya sebagai kekuatan kritis terhadap penguasa, apatisme pun melanda sebagian mahasiswa. Kendati demikian, kecenderungan apatisme ini tidak sampai meluas ke seluruh kalangan mahasiswa. Sebagai alternatif terhadap suasana a-politis dikehidupan intra kampus ini, dikembangkanlah medan perjuangan baru yang dianggap mahasiswa tidak akan tersentuh kekuasaan represif penguasa melalui tangan birokrat kampus, medan perjuangan baru itu, yaitu kelompok-kelompok studi (study club), maka bermunculanlah kelompok-kelompok studi ini di awal tahun 1980-an di kampus-kampus di Indonesia.

Terdapat dua arus besar kelompok studi mahasiswa yang semarak ketika itu, kelompok mahasiswa yang mengkaji ilmu-ilmu sosial kritis dan kelompok mahasiswa yang mengkaji wacana sosial keagamaan Islam. Kelompok studi ilmu sosial kritis kemudian bertransformasi menjadi gerakan radikal melawan pemerintah Orde Baru dipertengahan tahun 1990-an, dengan membentuk Partai Rakyat Demokratik (PRD), sedangkan kelompok studi sosial keagamaan membentuk jaringan Lembaga Dakwah Kampus (LDK) yang tersebar dihampir seluruh perguruan tinggi di Indonesia. Dari jaringan LDK, kemudian kelompok sosial keagamaan ini mendirikan Kesatuan Aksi Mahasiswa Muslim Indonesia (KAMMI) diakhir kekuasaan Orde Baru dan mendirikan Partai Keadilan (PK) di awal reformasi (Damanik,2002).

Perkembangan kemudian, memasuki tahun 1989, eksistensi kelompok-kelompok studi ini tidak bertahan lama, sebagian aktifis mahasiswa mengalihkan aktifitas perjuangan dengan mendirikan wadah-wadah pemberdayaan masyarakat dalam bentuk Lembaga Swadaya Masyarakat (LSM) dan Komite Aksi.

Kemunculan LSM dan Komite Aksi merupakan hasil kontemplasi kelompok studi yang berhasil memupuk kesadaran dan pemahaman tentang realitas politik yang dihadapi masyarakat ketika Orde Baru, bahwa perubahan sistem politik tidak bisa dilakukan melalui serangkaian diskusi-diskusi, tetapi harus dipraksiskan dalam aksi-aksi nyata, terutama melakukan pembelaan (advokasi) terhadap massa rakyat yang mengalami peminggiran sistematis oleh negara.

Bentuk solidaritas mahasiswa terhadap penderitaan rakyat ditunjukan dengan mengirimkan beberapa aktifis untuk diterjunkan sebagai organisatoris rakyat ke daerah konflik baik itu konflik agraria atau peridustrian, salah satu tugas organisatoris rakyat adalah memberikan pendidikan politik kepada rakyat, bentuk pendidikan politik itu diantaranya teknik mediasi, mengorganisir massa dan pelatihan demonstrasi. Bentuk nyata dari aksi LSM dan komite aksi adalah pembelaan atas penggusuran tanah petani dalam kasus Kedung Ombo, inilah kasus awal yang berhasil menstimulasi integrasi antara mahasiswa dengan masyarakat.

Bersatunya mahasiswa dengan rakyat membuat pemerintah Orde Baru khawatir bisa menciptakan gerakan people power yang akan merongrong kekuasaanya, cara pemerintah menghentikan proses intergrasi mahasiswaa-rakyat ini dengan menarik kembali mahasiswa untuk beraktifitas di dalam kampus. Kebijakan NKK/ BKK dicabut, sebagai gantinya ditetapkan Senat Mahasiswa Perguruan Tinggi (SMPT) melalui SK No. 0457/U/1990, sebagai organisasi kemahasiswaan di dalam kampus, yang terdiri dari Senat Mahasiswa Fakultas (SMF) dan Unit Kegiatan Mahasiswa (UKM). 
1999, tetapi perolehan suaranya kecil, partai ini hanya memperoleh beberapa kursi di DPRD, tidak mampu melampaui abang batas electoral threshold secara nasional, sehingga PRD tidak berhak menjadi peserta pemilu ditahun 2004. Pemilu 1999 menjadi pemilu pertama serta terakhir yang diikuti PRD, meski secara institusi kepartaian, PRD tidak lagi menjadi partai elektoral, secara politik partai ini masih eksis sampai sekarang, terbukti mereka masih melakukan aktifitas politik. Dari narasi singkat diatas tentang PRD, penulis tertarik menjadikan partai ini menjadi objek kajian, terdapat beberapa alasan yang mendasari penulis menjadikannya sebagai objek penelitian. Pertama, pro-kontra menafsirkan ideologi dan gerakan PRD, terdapat dua pendapat umum tentang ideologi dianut PRD, menurut Daniel Dhakidae (2003:724), PRD secara intelektual menerapkan Marxisme sebagai landasan berpikir, yaitu berpikir untuk melawan, dari segi praktis, PRD mengambil semua jalan perlawanan dari demonstrasi dan pemogokan untuk memperjuangkan kepentingan politiknya. Sedangkan menurut Franz Magnis Suseno (2006:5), manifesto PRD meskipun sangat radikal dan keras, ternyata tidak memuat unsur-unsur Marxis dan Komunis, tidak ada kalimat penghancuran kaum kapitalis, justru PRD menuntut dibuatnya sistem multi partai, padahal komunisme itu menganut monopartai, serta secara eksplisit PRD mendukung adanya usaha swasta, sangat kontradiksi dengan sistem Komunis yang menginginkan sentralisme ekonomi oleh negara. Dari kedua argumentasi kontradiksi diatas, maka penulis ingin kembali mendalami ideologidangerakanPRD.Kedua, literaturpolitik Indonesia kontemporer umumnya, menarasikan partai-partai politik besar, terdapat kelangkaan referensi mengenai peran partai-partai politik "kecil" dalam pentas politik nasional, padahal PRD termasuk partai politik fenomenal ketika Orde Baru berkuasa, satu-satunya partai politik yang berani terang-terangan menjadikan program-program politiknya bersebrangan dengan kebijakan politik pemerintah Orde Baru. Ketiga, terdapat kelangkaan studi tentang peran politik PRD diera refomasi, umumnya publik politik Indonesia hanya mengenal eksistensi politik PRD ketika Orde Baru berkuasa. Belum terdapat studi yang menjelaskan kiprah politik partai ini ketika rezim demokratis terbentuk di negeri pasca runtuhnya Orde Baru.
Dari beberapa alasan itu penulis tertarik melakukan riset tentang kiprah politik PRD diera reformasi, tentu studi tentang PRD ini kurang tepat menempatkanya sebagai partai politik elektoral, kecuali ketika pemilu 1999, yang paling tepat menempatkanya sebagai sebuah gerakan sosial.

Berdasarkan latar belakang diatas, ada dua pertanyaan pokok yang menjadi fokus dalam tulisan ini: (1) Bagaimana proses transformasi gerakan sosial (kelompok studi) menjadi Partai Rakyat Demokratik (2) Bagaimana kiprah politik Partai Rakyat Demokratik di era reformasi.

Penulis menggunakan metode deskriptif dengan pendekatan kualitatif, menganalisis data ditunjukan atau disajikan bukan dalam bentuk statistik, tetapi berupa menggambarkan atau menarasikan suatu fenomena politik yang terjadi. Penulis menggunakan data literatur, yaitu data yang tersusun dalam bentuk tertulis, seperti buku, koran, artikel dan jurnal. Dalam tulisan ini penulis menggunakan kerangka teori gerakan sosial.

Gerakan sosial menurut Robert Miesel (2004), didefinisikan sebagai seperangkat keyakinan dan tindakan yang terlembagakan yang dilakukan oleh sekelompok orang untuk memajukan atau menghalangi perubahan di dalam sebuah masyarakat. Kemunculan gerakan sosial tidak bisa dilepaskan dari perkumpulan massal (mass society) dan tingkah laku kolektif (collective behavior). Elemen kunci dari setiap gerakan sosial menurutnya adalah organisasiorganisasi gerakan, bukan individu-individu, organisasi-organisasi tersebut merupakan unitunit penggerak dari sebuah gerakan kemasyarakatan dan menjadi objek utama dan paling penting dalam sebuah penelitian.

Para anggota (aktor) kelompok gerakan sosial diidentifikasikan sebagai orang-orang yang tidak puas dan kecewa, yaitu mereka yang tersingkir dalam kehidupan kelompok marginal ditengah masyarakat, hingga kelompok minoritas yang tertekan. Selain itu orang-orang yang terlibat dalam gerakan sosial sendiri selalu memiliki pertimbangan-pertimbangan yang bisa diterima oleh akal sehat, jadi dapat disimpulkan bahwa sebuah gerakan sosial akan senantiasa melibatkan individu atau sekelompok orang yang terorganisir secara baik dan rapih, untuk melakukan sebua perubahan yang menyentuh dimensi moral, sosial, politik maupun ekonomi. 
bagi tumbuhnya sikap idealisme itu. Memasuki tahun 1980-an format baru gerakan mahasiswa melalui kelompok-kelompok diskusi mulai marak dibeberapa kota di Indonesia, bentuk forum non-formal ini menjadi pilihan aktifis mahasiswa, dikarenakan sifatnya yang fleksibel serta tidak mudah disentuh oleh tangan-tangan penguasa (Rahmat \& Najib, 2001:60-61).

Kelompok-kelompok studi ini sangat beragam bentuknya, kebanyakan eksistensi mereka tidak terstruktur, hanya melibatkan sekelompok kecil mahasiswa, kelompok studi ini biasanya mengadakan pertemua reguler didekat kampus untuk mendiskusikan teori-teori sosial politik, perkembangan pembangunan, masalahmasalah politik lokal dan beragam tema lain yang berhubungan dengan masalah kemasyarakatan. Dalam perjalanannya kemudian, beberapa kelompok studi ini semakin terorganisir serta mulai menerbitkan media publikasinya berupa jurnal reguler, yang menyajikan wacana intelektual argumentatif mengkritisi jalannya kebijakan pembangunan negara (Sidiq, 2003:60).

Periode 1980-an bisa dicatat sebagai aksi mahasiswa yang berkonsentasi sebagai kelompok pencari bahan bacaan untuk memperkuat basis teori bagi kelompok studi yang mereka kembangkan (Urbaningrum, 1999:175). Bagi kelompok studi yang mengkaji teori-teori sosial barat, mereka mencoba mencari jawaban teoritis dari problem kapitalisme yang tumbuh di Indonesia, akhirnya jawaban itu mereka dapatkan dalam teori-teori kiri yang ketika itu bahan-bahannya sangat sulit diperoleh secara terbuka, mengingat pemerintah Orde Baru mengeluarkan kebijakan pelarangan terhadap buku-buku berhaluan Sosialisme, Marxisme dan Komunisme.

Kelompok-kelompok studi sosial barat ini kemudian banyak mengkaji pemikiran kiri seperti Teori Kiri Baru, Teori Ketergantungan, Teologi Pembebasan, Ide Revolusi dari Lenin dan Mao Tse Tung serta bacaan-bacaan kiri lainnya. Teori kiri dibaca kelompok studi ini untuk mencari basis ilmiah-materialistik proses penindasan yang terjadi, teori-teori kiri seakan memberi jalan keluar dari masalah penindasan pembangunan kapitalisme yang dijalankan Orde Baru, pembacaan mereka terhadap teori-teori kiri sebagai bentuk pencarian wacana alternatif di luar ideologi kapitalisme yang dikembangkan oleh negara (Gunawan, et al, 2009:10-11).
Kegandrungan anak-anak muda terhadap wacana kiri diakui oleh Budiman Sudjatmiko, salah satu aktifis kelompok studi di Yogyakarta, yang kelak menjadi Ketua Umum Partai Rakyat Demokratik (PRD).

"Lebih bisa kurasakan bahwa berinteraksi dengan kelompok-kelompok studi mahasiswa yang mengupas nasib petani dan kapitalisme perkebunan membuatku lebih memahami sistem yang membawa wabah kemiskinan dan kematiaan di desaku. Sejak saat itu, pergumulan cakrawala pemikiranku, bersama rekan-rekan HMI UII semakin lama semakin intens. Mereka mulai memijamiku beberapa buku Teori Gerakan Sosialis yang cukup dalam, ada seorang mahasiswa ekonomi UII yang memijamiku buku "Capital" karya Karl Marx. Buku itu dibelinya di New York saat dia berkunjung kesana. Pada masa itu, "Capital" adalah buku terlarang di Indonesia, proses pinjam meminjam buku itu terjadi secara sembunyi-sebunyi, menyerupai transaksi narkotika" (Sujdatmiko, 2013:258).

"Pemikiran Neo-Marxis yang kubaca itu merupakan sebuah perluasan dari pandangan Marx, yang melihat proses penghisapan terjadi secara vertikal, oleh kaum borjuis terhadap kaum proletar..setelah pemikiran Neo-Marxis, aku mulai berkenalan dengan pemikiran Frankfurt School, mereka adalah kelompok intelektual yang mengkaji Marx secara interdisipliner, tokoh-tokoh yang sangat populer dari kelompok ini adalah Theodor Adorno, Erich Fromm, Jurgen Habermas, Max Horkheimer dan Herbert Marcuse yang meninjau Marx dari presfektif sosiologis, psikologis dan teori komunikasi" (Sujdatmiko,2013:263-264).

Kelompok studi bermunculan diberbagai kota, khususnya di Yogyakarta, terdapat dua kelompok studi terkenal saat itu, yaitu (1) Kelompok studi yang menghimpun aktifis mahasiswa FH-UII yang terletak di Gang Rode. Kelompok diskusi ini mengkaji pemikiran Marxisme, Neo-Marxis dan Frankfurt School, dan (2) Kelompok Studi Sosial Palagan (KSSP) yang menghimpun mahasiswa Fisip UGM, tema diskusi di KSSP lebih menitikberatkan pada masalah-masalah ekonomi politik, buku disertasi Arief Budiman di Harvard yang berjudul "Jalan Demokratis Ke Sosialisme : Pengalaman Chile 
ternyata tidak menjalankan peran yang telah digariskan dalam kongres pendiriannya. Menurut Budiman Sudjatmiko, PRD selain tidak mampu mendorong potensi perlawanan massa rakyat, juga gagal membangun aliansi anti kediktaktoran Presiden Soeharto bersama kekuatan oposisi lain. Terlebih, kultur oposisi yang dikembangkan sekadar statement-statement politik belaka, seperti para politisi elit, padahal sebagian besar kader PRD menyakini pemerintahan Soeharto hanya bisa ditumbangkan dengan gerakan massa rakyat demokratik, bukan melalui statement melalui media massa (Gunawan, 1999:22).

Kecenderungan lunaknya model oposisi politik PRD, mengakibatkan munculnya perselisihan paham diantara para anggotanya, akhirnya di bawah inisiatif Budiman Sudjatmiko, PRD membentuk Komite Penyelamat Organisasi. Komite inilah yang mengumpulkan tanda tangan dari anggota PRD untuk mengadakan Kongres PRD di Kaliurang Yogyakarta pada April 1996. Dalam kongres di Kaliurang ini akhirnya Budiman Sudjatmiko di tunjuk sebagai Ketua Umum, kemudian PRD dideklarasikan kedua kalinya di kantor YLBHI, Jakarta tanggal 22 Juli 1996, dengan mengubah format organisasi menjadi partai politik (Fatah, 2000:100.)

Pertimbangan perubahan bentuk PRD dari "persatuan" menjadi "partai politik", bahwa hakikatnya perjuangan demokrasi merupakan perjuangan bernuasa politik, karena itu wadah yang dianggap tepat memperjuangkan cita-cita tersebut, merupakan wadah yang berbentuk partai politik (Gunawan, 1999: 81). Dalam deklarasi kedua PRD, dicantumkan asas Partai Rakyat Demokratik (PRD) berasas SosialDemokrasi-Kerakyatan, subtansi dari asas ini ialah demokrasi untuk kesejahteraan massa rakyat dengan tujuan membebaskan rakyat dari penindasan. Bagi PRD memperjuangkan demokrasi tidak saja dalam tataran legal-formal saja, tetapi bagaimana demokrasi itu mampu di implementasikan dalam kehidupan nyata demi kesejahteraan (Gunawan,1999: 77-79).

Menurut Budiman Sudjatmiko, beberapa program politik PRD diantaranya adalah (1) Mengangkat kembali wacana pencabutan paket atas lima Undang-Undang, yaitu UU Tentang Pemilihan Umum, UU Tentang Partai Politik dan Golongan Karya, UU Tentang Susunan, Kedudukan, Tugas dan Wewenang DPR/MPR, UU Tentang Referendum dan UU Tentang
Organisasi Massa. Kelima undang-undang itu bagi PRD menjadi penghalang terbesar proses demokratisasi (Budiman Sujdatmiko,2013:421). (2) Mencabut Undang-Undang Subversif PNPS No. 11 Tahun 1963, yang dinilai mematikan sikap kritis warga negara terhadap kebijakan pemerintah Orde Baru. (3) Menuntut supremasi sipil dengan pencabutan dwifungsi ABRI, mengembalikan intitusi militer kembali kebarak. (4) Dihentikannya semua bentuk diskriminasi terhadap kaum perempuan. (5) Meminta pengadilan Internasional untuk mengadili pemerintah Orde Baru atas pembantaian massa ketika tahun 1965. (6) Menekan pemerintah Orde Baru untuk mempertanggungjawabakan invasi serta pendudukan Timor-Timur dan melaksanakan referendum di bawah pengawasan badan-badan dunia. (7) Mendesak MPR untuk mengadakan Sidang Istimewa (SI) menutur pertanggungjawaban Soeharto selama memim-pin negara Republik Indonesia (Gunawan, 1999: 85-88).

Pada peristiwa 27 Juli 1996, Partai Rakyat Demokratik (PRD) dituduh pemerintah sebagai aktor dibelakang aksi huru-hara yang membakar Jakarta, melalui media massa dan elektronik, pemerintah Orde Baru menyiarkan propaganda secara berulang-ulang, bahwa aksi kerusuhan serta pembakaran itu didalangi oleh PRD, sebuah partai yang dinilai sebagai reinkarnasi Partai Komunis Indonesia (PKI). Lima hari setelah kerusuhan 27 Juli 1996, pemerintah menginstruksikan penangkapan terhadap para pimpinan PRD. Selain melakukan penangkapan dan penahanan, Orde Baru terus menerus menyiarkan propaganda bahwa PRD partai berhaluan komunis.

Salah satu petinggi Angkatan Bersenjata Republik Indonesia (ABRI) saat itu, Asisten Sosial Politik (Assospol) Mayjen Suwarno Adiwijiyo, menjelaskan bahwa PRD merupakan salah satu dari banyak organisasi penganut paham komunis. Menurutnya komunis biasanya menggunakan teori gunung es, yakni yang muncul kepermukaan hanya sebagaian kecil, sedangkan sebagian besar lain berada di bawah permukaan (Kompas. 1996).

Pendapat Assospol ABRI tersebut diperkuat pernyataan Kepala Staf Sosial Politik (Kassospol) ABRI, Letjen Syarwan Hamid, yang menjelaskan persoalan PDI tidak lagi dianggap sebagai masalah internal antara 
pendukung Megawati dengan Soerjadi, tetapi menjadi permasalahan pemerintah, karena berdasarkan bukti-bukti yang terkumpul organisasi masyarakat yang bernama PRD, memiliki kepentingan atas konflik internal PDI, mereka memiliki pemikiran-pemikiran untuk menjatuhkan pemerintahan Orde Baru melalui aksi "people power" memanfaatkan ketidakpuasaan massa pendukung Megawati. Lebih lanjut, menurutnya terdapat kemiripan antara PKI dan PRD, tampak dari filosofi, landasan dan tujuaanya. Misalnya sifat dan watak PRD berdasar dokumennya, merupakan partai politik yang berwatak progresif revolusioner, berasaskan non-pancasila, yakni sosial demokrasi kerakyatan, dengan terlibat aktif dalam perjuangan kaum buruh, tani dan rakyat tertindas. Semua itu menurut Syarwan Hamid, sangat mirip dengan konsep Marxisme-Leninisme (Kompas, 996).

Menariknya dukungan atas propaganda Orde Baru terhadap PRD, mendapat dukungan luas beberapa tokoh nasional, misalnya Amien Rais, Ketua PP Muhammadiyah saat itu, dalam salah satu artikelnya ia menulis, bahwa sinyalemen come back-nya komunis bukan dibuat-buat ABRI dan pemerintah, tetapi sesuatu yang riil. Menurutnya gerakan PRD, apabila dilihat dari slogan-slogan yang digunakan mirip dengan komunisme, tetapi menurut Amien Rais, PRD itu belum menjadi komunis sejati masih berupa pseudo communism, artinya belum komunis, tetapi elemen-elemennya sudah mengarah ke komunisme (Risalah.1996),

Lebih jauh menurut Amien, terdapat tiga kekuataan sosial politik di Indonesia. Pertama, kekuataan status quo, kekuataan ini hanya ingin mempertahankan kekuasaan (kemapanan), ini merujuk kepada pendukung setia rezim otoriter. Kedua, kekuataan anti status quo, yang mengandalkan kekuataan rakyat, mereka selalu berbicara mengatasnamakan rakyat, tetapi memiliki strategi politik bumi hangus, dengan cara-cara meradikalisasi massa rakyat. Ketiga, kekuataan reformatif, kelompok yang menginginkan perubahan secara kritis, terbuka dan demokratis tetapi tidak menghalalkan segala cara. Meskipun dalam komentarnya Amien Rais tidak memposisikan PRD berada diposisi mana, menurut penulis secara tidak langsung Amien Rais mengkritik startegi gerakan PRD dalam melawan rezim Orde Baru (Kompas, 1996)
Pendapat senada diutarakan Anas Urbaningrum (1997:173), salah satu tokoh HMI, dalam salah satu artikelnya ia menulis walaupun manifesto PRD lebih dekat ke ideologi kaum sosial demokrat (sosdem) yang partai-partainya kini banyak berkuasa di Eropa Barat, tetapi secara metodologis aksi-aksi dilakukan PRD tampaknya lebih konsisten dengan doktrin perjuangan kelas Leninisme, artinya menurut Anas, terdapat kontradiksi di dalam tubuh PRD antara level konseptual ideologis dengan agenda aksi yang dilakukan.

Mudahnya berbagai pihak menuduh PRD memiliki keterkaitan dengan komunisme, sepertinya disebabkan partai ini menjadi satusatunya partai politik di masa Orde Baru yang tidak mencantumkan asas Pancasila sebagai asasnya, ini berbeda dengan Partai Uni Demokrasi Indonesia (PUDI) bentukan DR. Sri Bintang Pamungkas, yang tetap mencantumkan Pancasila sebagai asas partai. Selain itu, PRD kerap menggunakan istilah-istilah serta jargon-jargon yang akrab digunakan PKI ketika masa tahun 1960-an (Mutiara, 1996).

Meskipun begitu, tidak semua kalangan menjustifikasi PRD sebagai komunis, ketika persidangan Budiman Sudjatmiko tahun 1997, beberapa saksi ahli dari kalangan ilmuan politik, salah satunya Prof. Dr. Deliar Noer, mengemukakan, dirinya tidak melihat PRD melalui manifestonya telah merongrong ideologi negara Pancasila, menurutnya bahasa yang digunakan aktifis PRD dalam manifestonya, merupakan bahasa-bahasa anak muda. Misalnya ketika Jaksa Penuntut Umum menanyakan kepada dirinya sependapat atau tidak dengan salah satu bunyi manifesto PRD : "di Indonesia tidak ada demokrasi". Atas pertanyaan itu Deliar Noer menjelaskan, bahwa demokrasi di Indonesia mengalami kemunduran, pemerintah cenderung korporatik, itu merupakan jawaban orang tua, sedangkan bahasa anak muda tidak seperti itu, bahasanya "tidak ada demokrasi". Contoh lain menurut Deliar, ketika dirinya dilarang pemerintah Orde Baru untuk tidak berkhotbah Idul Fitri, bahasa anak muda berbeda, bahwa "Deliar Noer di pasung pemerintah". Selain Deliar Noer, saksi ahli lain, Prof. Dr. Frans Magnis Suseno, menjelaskan bahwa keseluruhan manifesto PRD, tidak bertentangan dengan Pancasila, terlebih salah satu program politik PRD, ingin menerapkan sistem multi 
partai, ini berbeda dengan komunisme yang berkecenderungan menerapkan partai tunggal (Kompas. 1997).

Perdebatan komunisme dalam PRD sepertinya tidak akan pernah tuntas, masingmasing pihak memiliki argumentasi dan alasannya sendiri-sendiri, karena sepertinya PRD memberikan ruang semua pihak untuk menafsirkan watak gerakan dan ideologi PRD. Tetapi, yang menarik ialah pernyataan Budiman Sudjatmiko (Kompas, 2001. Pendapat PRD dan KAMMI, tanggal 8 Maret), mengenai visi PRD, bahwa platform gerakan PRD itu sangat jelas, yakni anti Orde Baru, anti militerisme, anti oligarki ekonomi dan politik. Ia mengakui gerakan PRD membawa visi "kiri" yang berbicara tentang buruh, petani dan masyarakat miskin kota. Pilihan atas visi kiri itu menurutnya, suatu persoalan hak asasi, sebagai sebuah konsekuensi atas pruralisme demokrasi, terpenting ide-ide tentang kebebasan, persamaan dan keadilan menjadi formulasi bersama setiap gerakan perubahan. Serta, terpenting menurut penulis, kiri itu tidak identik dengan komunis, kiri adalah kritis, populis dan anti kemapanan. Jadi setiap gerakan yang menentang penindasaan kapitalisme dengan label ideologi apapun, bisa dimasukan sebagai gerakan kiri.

Setelah penangkapan tokoh-tokoh PRD, seperti Budiman Sudjatmiko, Petrus Hari Harianto, Jacobus Eko Kurniawan, Garda Sembiring, Dita Indah Sari dan lain-lain. Organisasi PRD bergerak di bawah tanah, maka untuk menghindari tindakan represif aparat militer, mereka tidak menggunakan nama, simbol dan bendera PRD. Mereka melakukan perlawanan, dengan menggunakan nama komite aksi. Menurut Max Lane (2007:180-185), terdapat beberapa bentuk aksi perlawanan yang dilakukan PRD selama bergerak di bawah tanah, diantaranya: (1) Melakukan aksi melumpuhkan kota Lampung, tanggal 10-11 Desember 1997 dengan aksi mogok supir angkutan umum, beserta aksi gabungan pelajar dan mahasiswa. (2) Ketika menjelang Pemilu 1997, memobilisasi sekitar 20.000 orang pendukung Megawati melakukan aksi memblokade Jalan Gajah Mada di Jakarta Pusat. (3) Memobilisasi massa pro Megawati mendukung setiap kampanye Partai Pesatuan Pembangunan (PPP) ketika Pemilu 1997. Bentuk mobilisasidenganmemproklamirkan aksi "MegaBintang”, kata Mega mengacu pada Megawati, sedangkan bintang merupakan lambang PPP. Koalisi ini di bentuk sebagai resistensi atas kemenangan Golkar pada setiap pemilu, juga mendelegitimasi PDI "versi" pemerintah. (4) Menyebarkan 600.000 selembaran anti pemerintah Orde Baru, selembaran itu berisi berbagai tuntutan-tuntutan yang menjadi program politik PRD. (5) Gerakan PRD di sektor mahasiswa, banyak membentuk komite-komite aksi, seperti di Kota Semarang di bentuk Aliansi Mahasiswa Semarang (AMS), komite aksi ini melancarkan unjuk rasa memprotes pemberitaan pers yang menyudutkan PRD.

Sedangkan, di Bandar Lampung muncul Persatuan Mahasiswa dan Pemuda Lampung (PMPL), yang melakukan pengorganisasian memboikot Pemilu 1997, aksi ini berakibat pada penangkapan tiga aktifis PMPL (Kompas, 2000. Budiman Sudjatmiko, Gerakan Mahasiswa Kini: Bersama Rakyat Tuntaskan Reformasi Total, tanggal 12 Desember 2000). Selain di Semarang dan Lampung, puluhan komite aksi mahasiswa, juga banyak didirikan di kota-kota lain, komite-komite aksi inilah yang banyak berperan besar dalam menggalang demonstrasi, bersama eleman pergerakan mahasiswa lain, ketika menggulingkan Presiden Soeharto pada Mei 1998.

\section{Kiprah PRD di Era Reformasi.}

Pemerintahan reformasi di bawah Presiden BJ. Habibie, pada tahun 1999 menerbitkan undang-undang partai politik baru, artinya era tiga partai ketika Orde Baru berkuasa telah berakhir, dalam undang-undang baru, setiap orang diberi kebebasan mendirikan partai politik yang akan menjadi peserta pemilu.

Menurut Budiman Sudjatmiko (2014:6263), perkembangan sistem kepartaian ini menimbulkan perdebatan dikalangan internal PRD. Perdebatan tersebut, menyangkut topik apakah PRD harus mengikuti atau tidak mengikuti pemilu pertama pasca runtuhnya Orde Baru. Sejatinya menurut Budiman, pengurus pusat PRD sepakat untuk tidak ikut serta menjadi peserta pemilu, mengingat basis massa PRD telah terkoyak-koyak setelah peristiwa 27 Juli 1996, serta beberapa aktifis kunci PRD menjadi korban penculikan yang belum kembali. Alasan lain, PRD merupakan partai politik yang awalnya didesain melakukan aksi massa dalam menghadapi kediktaktoran Orde 
Baru, bukan dirancang menjadi partai elektoral untuk memenangkan pemilu. PRD disiapkan mengorganisir aktifis-aktifis militan, bukan menjadi partai yang bersifat terbuka, yang umumnya menjadi tipikal partai elektoral. Para pengurus pusat PRD sadar betul, apabila partai ikut berkompetisi, partai mereka tidak akan mungkin memenangkan pemilu.

Akhirnya PRD terbelah dua kubu, antara yang menolak mengikuti pemilu, melihat fakta ketidaksiapan PRD, dengan pihak yang memilih ikut pemilu, ajang menyampaikan pesan politik kepada masyarakat. Karena tidak terdapat titik temu, pada akhirnya dilakukan voting internal kader, dengan hasil voting yang mengamanatkan PRD harus mengikuti Pemilu 1999 (Budiman Sudjatmiko 2014:64). Pada tanggal 7 Juni 1999 dilaksanakan Pemilihan Umum Legislatif, PRD seperti yang sudah diprediksi, gagal meraih kursi di DPR RI, dan hanya memenangkan sejumlah kursi dibeberapa parlemen daerah atau DPRD (Budiman Sudjatmiko 2014:67).

Pasca Pemilu 1999, PRD kembali menjalankan peran sosial politiknya sebagai organisasi pergerakan sosial, sama seperti ketika Orde Baru berkuasa. Menurut Budiman Sudjatmiko, metode pengorganisasian tetap sama seperti sebelumnya, menggunakan metode live in dengan membangun kontak terlebih dahulu, lalu mengajak diskusi tentang kondisi sosial politik. Dari kegiatan diskusi ini, kemudian para aktifis partai mulai "menginjeksi" kesadaran massa rakyat, dengan menanamkan kesadaran baru, diharapkan kemudian bersedia melibatkan diri dalam aktifitas politik, dari penyebaran selembaran sampai terlibat aksi massa (Kompas, 2000).

Selain tetap melakukan aksi advokasi melalui live in, PRD juga menjalin koalisi strategis bersama kekuataan-kekuataan pro demokrasi, dengan mendirikan Koalisi Nasional Anti Orde Baru (Lindas Orba). Salah satu kegiatan Lindas Orba yang kemudian menjadi isu nasional adalah pelaksanan Konferensi Asia Afrika bertema "Dampak Ekonomi Neoliberalisme di Dunia Pertama dan Ketiga", konferensi itu merupakan hasil kerja sama PRD dengan Lembaga Increase, yang dihadiri banyak kalangan dari LSM, ormas dan partai politik, juga kaum akademis dari dalam dan luar negeri, seperti Amerika Serikat, Prancis, India, Pakistan, Australia, Jepang, Kanada, Selandia Baru dan Bangladesh (Kompas, 2001).
Sampai tahun 2009, aktivitas politik Partai Rakyat Demokratik (PRD) lebih bersifat ektra parlementer, berupa kegiatan advokasi serta pemberdayaan kaum marginal, tidak masuk ke dalam sistem pemerintahan mengingat sampai pemilu keempat era reformasi (2004, 2009 dan 2014), PRD tidak berpartisipasi sebagai peserta pemilu. Baru memasuki tahun 2010 terjadi dinamika di dalam tubuh PRD, partai berlambang bintang dan gerigi roda ini melakukan langkah besar, dengan merubah asas partai dari sosial demokrasi kerakyatan ke asas pancasila.

Menurut Agus Jabo Priyono, Ketua Umum Komite Pusat Partai Rakyat Demokratik (KPP PRD) periode 2015-2020, pilihan merubah asas dari sosial demokrasi kerakyatan ke pancasila menunjukan, bahwa PRD ingin menjadi partai terbuka yang menampung semua komponen bangsa, tidak saja kalangan aktifis muda pergerakan. Perubahan asas PRD dilakukan saat kongres ketujuh pada Maret 2010, di Salatiga Jawa Tengah. Tentu perubahan asas PRD ini diwarnai perdebatan internal dalam kongres, bahkan perdebatan tersebut hampir berujung perpecahan. Tetapi, menurut Agus Jabo Priyono, perpecahan tidak terjadi, karena kader PRD memaknai perdebatan tersebut, merupakan upaya untuk mencapai bentuk dan pola perjuangan partai yang terbaik. Maka diatas kondisi bangsa yang telah berubah, tentu PRD dituntut beradaptasi dengan perubahan kontelasi politik nasional, format gerakan politik PRD harus berbeda, tidak harus sama dengan gerakan ketika PRD didirikan di tahun 1996. Masa kediktaktoran politik sudah berakhir, berganti dengan era keterbukaan dan kebebasan, strategi perlawanan dengan cara-cara radikal, sudah tidak menemukan relevansinya, perjuangan dengan format baru dalam demokrasi elektoral menjadi pilihan cerdas (http://www.prd.or.id, 2012)

Setelah tuntas menginternalisasi ideologi pancasila, langkah selanjutnya yang dilakukan Partai Rakyat Demokratik (PRD) ialah menjalin koalisi persatuaan nasional dengan platfrom anti imperialisme. Persatuan nasional merupakan upaya PRD untuk merangkul sebanyak-banyaknya sekutu, agar berada satu barisan dalam perjuangan menghadapi imperialisme. Sedangkan, strategi perjuangan dilakukan secara terbuka 
guna mengisi ruang-ruang publik dengan terus menerus mengkampanyekan garis perjuangan. (http://www.berdikarionline.com, 2015).

Bahkan satu pihak yang bersedia menerima aliansi politik ini merupakan salah satu partai politik Islam terkemuka di Indonesia, yaitu Partai Keadilan Sejahtera (PKS). Menurut Soeripto, salah satu anggota Majelis Syuro PKS, PRD merupakan salah satu partai kader yang berjuang untuk rakyat. Baginya, jangan melihat PRD dari masa lalunya, tetapi di masa depan dalam usaha ikut membangun bangsa. Lebih lanjut menurutnya, PKS akan membuka tangan selebar-lebarnya untuk PRD, bahkan menurutnya PRD jangan merasa jagoan ingin menghadapi neoliberalisme sendirian, tetapi harus bersatu dengan partai-partai lain, termasuk dengan PKS (http://citizendaily.net, 2015).

Langkah pertama yang dilakukan PRD untuk mengusir imperialisme asing, mewacanakan untuk membatakan semua produk undangundang yang dinilai berbau neoli-beralisme (neolib). Menurut Agus Jabo, banyak produk undang-undang yang berpihak kepada kepentingan asing, bahkan sebagian besar UU itu dibuat menurut LOI dengan IMF dan arahan Bank Dunia. SeluruhUU tersebutmenjadi sarana legal untuk berbagai proyek neoliberal di Indonesia. Menurutnya, diantara undang-undang itu, adalah UU Nomor 22 Tahun 2011 Tentang Migas, UU Momor 4 Tahun 2009 Tentang Minerba, UU Nomor 25 Tahun 2007 Tentang PMA, dan UU Nomor 7 Tahun 2004 Tentang SDA, UU No.18/2004 Tentang Perkebunan, UU No.19/2004 Tentang Kehutanan, berbagai perundangan itu yang menyebabkan modal asing mengusai kekayaan alam nasional di sektor migas $(85-90 \%)$, kekayaan batubara $(75 \%)$, mineral (89\%), perkebunan (50\%), dan lain-lain. Sebagai realisasi tuntutan pembatalan berbagai undang-undang pro kepentingan asing, Partai Rakyat Demokratik (PRD), kemudian menggagas Gerakan Kembali Ke-Pasal 33, karena bagi PRD sejak awal Pasal 33 UUD 1945 ini menggariskan bahwa ekonomi Indonesia harus terbebas dari kolonialisme dan imperialisme asing, dengan berpijak pada kemandirian (http// www.berdikarionline.com, 2015).

Wujud kongkrit Gerakan Kembali Ke Pasal 33, PRD memobilisasi massa melakukan aksi demontrasi besar-besar dibeberapa daerah, dengan puncak aksi sendiri digelar di depan gedung Mahkamah Konstitusi (MK). Dari beberapa narasi peran politik PRD di era reformasi, salah satu peran terpenting ialah mendeklarasikan diri sebagai partai politik yang akan berkompetisi di Pemilu 2019, keputusan melibatkan diri sebagai kontestan pemilu, diputuskan pada Kongres Ke-8 yang di gelar pada 24-26 Maret 2015.

Menurut Agus Jabo Priyono, alasan PRD menjadikan Pemilu 2019 sebagai target perjuangan partai, karena PRD selain didirikan untuk merebut kekuasaan dari tangan Soeharto, PRD juga didirikan untuk bisa berkuasa, tentu kekuasaan yang dimaksud PRD adalan kekuasaan dengan penggunaan semua instrumen dan sumber daya negara untuk kemakmuran rakyat. Jadi bukan untuk golongan dan orang perorangan. Kepentingan umum harus diletakkan di atas kepentingan pribadi, serta kewajiban terhadap bangsa dan negaralah yang harus diutamakan. Menurutnya, adapun langkah yang akan ditempuh PRD untuk menarik simpati rakyat pada Pemilu 2019, yaitu dengan cara menempatkan rakyat sebagai subjek politik, partai akan mengajak rakyat, mendidik rakyat, membuat organaniasi-organisasi rakyat, termasuk juga menyelesaikan persoalanpersoalan rakyat. Dengan itu, rakyat akan tahu partai mana yang benar-benar berjuang untuk rakyat. Partai mana yang harus didukung (http:// www.berdikarionline.com, 2015).

Bagi para pengurus PRD peluang partai ini meraih kursi di DPR RI pada Pemilu 2019 cukup besar, karena saat ini jumlah kader PRD yang tercatat terdapat belasan ribu orang, yang sudah dikaderisasikan melalui organisasi-organisasi yang berafiliasi dengan PRD, seperti Serikat Tani Nasional (STN), Serikat Rakyat Miskin Indonesia (SRMI), Front Nasional Perjuangan Buruh Indonesia (FNPBI), dan Liga Mahasiswa Nasional Untuk Demokrasi (LMND). Terlebih, mayoritas lembaga suvey telah mencatat $80 \%$ pemilih Indonesia dikategorikan sebagai floating mass (massa mengambang). Hanya $20 \%$ yang menjadi afiliator kepada partai politik. Kondisi objektif ini akan dimaksimalkan oleh PRD untuk masuk ke medan politik elektoral di tahun 2019 nanti (http://www.berdikarionline.com, 2015).

Itulah narasi tentang terbentuknya PRD dari masa Orde Baru sampai era reformasi.

Terdapat beberapa poin menurut penulis 
yang harus digarisbawahi, gerakan mahasiswa tahun 1977/78 pemerintahan Orde Baru mengeluarkan kebijakan NKK/BKK dengan tujuan membatasi aktifitas politik mahasiswa di dalam kampus. Kebijakan ini membuat mahasiswa memformat ulang gerakannya, dari gerakan bersifat massif menjadi gerakan literasi (membaca dan menulis), teori-teori kiri menjadi salah satu referensi yang menjadi tema diskusi mahasiswa ketika itu, melalui kelompokkelompok studi ini, bahan bacaan terlarang itu menyebar dari satu tangan ke tangan lain.

Gerakan mahasiswa era 1990-an ini muncul bukan dalam ruang kosong, kahadiran mereka merupakan sebuah jawaban atas berbagai kebijakan pemerintah Orde Baru, mereka merupakan lapisan kelas menengah yang mengalami kekecewaan kepada pemerintah. Pilihan mereka mengkaji ideologi kiri dilatarbelakangi arah ekonomi Indonesia yang berkiblat ke barat. Tetapi, kiri yang dimaknai mahasiswa berbeda dengan makna kiri dari pemerintah, bagi mahasiswa kiri artinya kritis melawan kemapanan kekuasaan, sedangkan oleh pemerintah dimaknai sebagai gerakan komunis-leninis. Pilihan atas ideologi kiri tentu sebuah pilihan sadar, karena mereka menemukan basis teori ini sesuai dengan situasi ketimpangan ekomomi dari kebijakan kapitalisme pemerintah.

Eksistensi kelompok studi tidak bertahan lama, para aktifis mahasiswa kemudian membentuk berbagai komite aksi dan lembaga swadaya masyarakat (LSM), perubahan format gerakan ini bertujuan mengaplikasikan teoriteori ke tataran aplikasi praksis di lapangan. Berbagai kasus penggusuran tanah milik petani serta hubungan produksi perburuan yang timpang menjadi konsen dari advokasi komitekomite aksi.

Perubahan bentuk gerakan sosial dari aktifitas literasi ke aksi, akhirnya merubah format gerakan mahasiswa menjadi lebih membumi, gagasan kritis teoritis yang sebelumnya terlontar ketika diskusi menuntut relevansinya dengan situasi lapangan sosial. Perubahaan ini juga, akhirnya menjadikan gerakan mahasiswa memperluas tema-tema gerakannya, seperti hak asasi manusia, lingkungan, ketenagakerjaan, agraria dan demokrasi.

Setelah membentuk berbagai komite aksi lintas sektoral, format baru berikutnya, yaitu mendirikan Partai Rakyat Demokratik (PRD), partai inimenjadi front persatuan kalangan aktifis mahasiswa dalam melawan kebijakan otoritertotaliter pemerintah Orde Baru. Aktifitas politik PRD hampir sama dengan komite aksi, tetap melakukan kegiatan-kegiatan advokasi dan pemberdayaan kelompok-kelompok marginal, meskipun berbentuk institusi kepartaian, pola gerakan PRD mirip dengan gerakan-gerakan sosial, partai ini memang didesain sebagai alat memobilisasi massa rakyat menjatuhkan Orde Baru, bukan diseting sebagai partai elektoral. Pantas saja, setelah Presiden Soeharto jatuh dari kekuasaanya, pada Pemilu 1999 PRD tidak memperoleh satu kursipun di DPR RI.

\section{SIMPULAN}

Setelah kekalahan di Pemilu 1999, PRD memutuskan untuk tidak melibatkan diri lagi disetiap moment pesta lima tahunan rakyat Indonesia. Keputusan tidak melibatkan diri menjadi kontestan pemilu menjadi keputusan bersama seluruh pengurus dan kader PRD. Otomatis aktifitas politik PRD setelah tahun 1999 bergerak di luar sistem politik, aktifitas politiknya terbatas hanya melakukan advokasi dan pemberdayaan masyarakat.

Pada kongres ditahun 2010, PRD kembali menarik perhatian publik politik Indonesia, keberanian merubah asas dari sosial demokrasi kerakyatan menjadi pancasila, mengejutkan pentas politik nasional. Bagaimanapun citra sebagai gerakan kiri sudah menjadi milik partai anak-anak muda ini, keputusan merubah asas partai, tentu saja akan membawa konsekuensi perubahan pola gerakan dan budaya politik partai, ini yang akan menjadi tantangan internal PRD ke depan. Terlebih lagi, pada kongres PRD ke delapan yang dilakukan secara terbuka, PRD mendeklarasikan kesiapannya menjadi salah satu kontestan di Pemilu 2019 mendatang. Transformasi terakhir ini menjadi tantangan kepada publik politik Indonesia, apakah PRD akan mampu bersaing dalam sistem demokrasi liberal, setelah kekalahannya di Pemilu 1999.

\section{DAFTAR PUSTAKA}

Budiyarso, Edy, 2000. Menentang Tirani : Aksi Mahasiswa 77/78. (Jakarta: PT. Grasindo).

Culla, Adi Suryadi, 1999. Patah Tumbuh Hilang Berganti : Sketsa Pergolakan 
Mahasiswa Dalam Politik dan Sejarah Indonesia 1980-1998. (Jakarta : PT. Raja Grafindo Persada).

Damanik, Ali Said, 2002. Fenomena Partai Keadilan: Transformasi 20 Tahun Gerakan Tarbiyah Di Indonesia. (Bandung: Teraju).

Dhakidae, Daniel, 2003. Cendekiawan dan Kekuasaan Dalam Negara Orde Baru. (Jakarta : Gramedia).

Damsar, 2010. Pengantar Sosiologi Politik (edisi revisi) (Jakarta : Kencana).

Fatah, Eeep Saefulloh, 2000. Penghianatan Demokrasi Ala Orde Baru : Masalah dan Masa Depan Demokrasi Terpimpin Konstitusional. (Bandung : Rosda).

Fatah, Eep Saefulloh, 2010. Konflik, Manipulasi dan Kebangkrutan Orde Baru. (Jakarta : Burung Merak Press).

Eep SaefullohFatah,2000.ZamanKesempatan: Agenda-Agenda Besar Demokratisasi Pasca Orde Baru. (Bandung: Mizan).

Gunawan, FX Rudy, 1999. Budiman Sudjatmiko Menolak Tunduk : Catatan Anak Muda Menentang Tirani. (Jakarta : Grasindo).

Gunawan, FX Rudy, 2009. Nezar Patria, Wilson dan Yayan Sopyan, Menyulut Lahan Kering Perlawanan: Gerakan Mahasiswa 1990-an. (Jakarta : Spasi dan VHR Book).

Haris, Syamsuddin (editor), 1998. Menggugat Pemilihan Umum Orde Baru. (Jakarta: Yayasan Obor Indonesia dan PPW LIPI).

Hasibuan, Muhammad Umar Syadat, 2008. Revolusi Politik Kaum Muda. (Jakarta: Yayasan Obor Indonesia).

Lasut, Jopie, 2011. Malari Kesaksian Seorang Jurnalis Anti Orde Baru: Melawan Soeharto dan Barisan Jendral Orde Baru. (Jakarta : Yayasan Penghayat Keadilan).

Lane, Max, 2014. Unfinished Nation (Yogyakarta : Penerbit Djaman Baroe).

Lane, Max, 2007. Bangsa Yang Belum Selesai: Indonesia, Sebelum dan Sesudah Soeharto. (Jakarta : Reform Intitute).

Najib, Andi Rahmat dan Mukhammad, 221. Gerakan Perlawanan Dari Masjid Kampus. (Surakarta : Purimedia).
Mirsel, Robert, 2004. Teori Pergerakan Sosial. (Yogyakarta : Resist Book).

Suharsono, 1996. Metode Penelitian Sosial. (Yogyakarta : Bentang Budaya).

Sujdatmiko, Budiman, 2013. Anak-Anak Revolusi. (Jakarta: Gramedia Pustaka Utama).

Sudjatmiko, Budiman, 2014. Anak-Anak Revolusi Buku Ke-2. (Jakarta: Pustaka Gramedia Utama)

Suseno, Franz Magnis, 2006. Berebut Jiwa Bangsa: Dialog, Perdamaian dan Persaudaraan. (Jakarta: Penerbit Kompas).

Sidiq, Mahfudz, 2003. KAMMI Dan Pergulatan Reformasi: Kiprah Politik Aktifis Dakwah Kampus Dalam Perjuangan Demokratisasi di Tengah Gelombang Krisis Nasional Multidimensi. (Solo : Era Intermedia).

Takwin, Bagus, 2009. Akar-Akar Ideologi. (Yogyakarta : Jalasutra).

Urbaningrum, Anas, 1999. Ranjau-Ranjau Reformasi: Potret Konflik Politik Pasca Kejatuhan Soeharto. (Jakarta : Rajawali Press).

Urbaningrum, Anas, 1997. Menuju Masyarakat Madani: Pilar dan Agenda Reformasi (Jakarta : Penerbit Yarsif Watampone).

\section{Koran dan Majalah}

Mutiara. 1996. Anggaran Dasar PRD Tidak Berdasarkan Pancasila. (Tahun XXXIX, 6-12 Agustus).

Kompas. 1996. Presiden : PRD Tak Akan Merembet: ABRI Akan Berantas Komunis Sampai Akar-Akarnya. (Kompas, 14 Agustus).

Kompas. 1996. Kassospol ABRI : Terlalu Naif Kalau Anggap ABRI Jadikan PRD Sebagai Kambing Hitam (Kompas, 1 Agustus).

Risalah. 1996. Amien Rais, Awas Bahaya Merah (Risalah No.8 Tahun XXXIV, Oktober).

Kompas.1996. DR. Amien Rais: Kader Komunis Tak Bisa Dimusnakan 100 Persen. (Kompas, 7 Agustus). 
Kompas. 1997.Saksi Ahli Prof. Dr. Deliar Noer : Bahasa Manifesto PRD Bahasa Anak Muda. (Kompas, 1 April).

Kompas. 2000. Budiman Sudjatmiko, Gerakan Mahasiswa Kini: Bersama Rakyat Tuntaskan Reformasi Total (Kompas, 12 Desember)

Kompas,2001. Pendapat PRD dan KAMMI (Kompas, 8 Maret)

\section{Internet}

http://www.prd.or.id/berita/20120627/ prd-tetapkan-pancasila-sebagai-asaspartai.html diakses pada tanggal 26 Juli 2015.

http://www.berdikarionline.com/ headlines/20150314/pengantarevaluasi-umum-kongres-prd-ke-viii. html,diakses tanggal 27 Juli 2015

http://www.berdikarionline.com/ headlines/20150306/agus-jabopriyono-prd-bersiapperjuangkanrepublik-keempat.html,diakses tanggal 28 Juli 2015.

http://citizendaily.net/pks-siap-bersatudengan-prd. diakses tanggal 28 Juli 2015.

http://www.berdikarionline.com/ lipsus/20140123/agus-jabo-priyono- tanpa-persatuan-nasional-untukmenyelesaikan-persoalan-bangsapemilu-2014-tidak-menghasilkanperubahan.html.diakses tanggal 29 Juli 2015.

http://www.berdikarionline.com/ lipsus/20140123/agus-jabo-priyonotanpa-persatuan-nasional-untukmenyelesaikan-persoalan-bangsapemilu-2014-tidak-menghasilkanperubahan.html, diakses tanggal 29 Juli 2015.

http://www.berdikarionline.com/kabarrakyat/gerakan-pasal-33/20111205/ prd-desak-mk-batalkan-semuaundang-undang-pro-neoliberalisme. html, diakses tanggal 29 Juli 2015

http://www.berdikarionline.com/kabarrakyat/20150324/prd-siap-bertarungdi-pemilu-2019.html, diakses tanggal 5 Agustus 2015.

http://sp.beritasatu.com/home/partai-rakyatdemokratik-target-rekrut-kaummuda/82392, diakses tanggal 5 Agustus 2015.

http://www.berdikarionline.com/ kabar-rakyat/20150324/prdsiap-bertarung-di-pemilu-2019. html\#ixzz3hwv1S7Jm, diakses tanggal 5 Agustus 2015. 